\title{
Representación de la mujer en el cine de David Fincher \\ El Club de la Lucha y La Red Social
}

\section{Resumen}

Fernando Ferrete-Poza

Universidad de Sevilla, España

http://dx.doi.org/10.12795/AdMIRA.2018.01.05

El cine del director David Fincher ha tenido una gran repercusión en los últimos años, siendo uno de los directores más laureados del cine contemporáneo. El club de la lucha (1999) y La red social (2010) son dos de sus películas más vistas y conocidas mundialmente. Con el objetivo de reflexionar sobre la presencia de la mujer en el cine de Hollywood y, concretamente, en el cine de David Fincher; se ha elaborado una metodología inspirada en las teorías de Francesco Casetti y Federico Di Chio para analizar el personaje de la mujer en ambas películas.

\section{Palabras clave}

Cine, David Fincher, La red social, El club de la lucha, feminismo, machismo, mujer.

\begin{abstract}
The cinema director David Fincher has experienced a big impact in the last years, being one of the most honoured director of the contemporary cinema. The Fight Club (1999) and The Social Network (2010) are two of the most watched and worldwide well-known films. With the aim of reflexing about the presence of the woman in the Hollywood cinema and, in particular, in the David Fincher's cinema, a methodology inspire on Francesco Cassetti and Federico Di Chio's theories has been developed in order to analyse the woman rol in both films.
\end{abstract}

\section{Keyword}

Cinema, David Fincher, The Social Network, Fight Club, feminism, sexism, woman. 


\section{Introducción}

David Andrew Leo Fincher es un productor y director de cine estadounidense nacido el 28 de agosto de 1962 en Denver (Colorado, Estados Unidos). Conocido internacionalmente como David Fincher, destaca en el cine americano con películas como El club de la lucha, Seven o El curioso caso de Benjamin Button. Ha sido nominado como mejor director en varias ocasiones en los premios más importantes del panorama internacional, los Óscar. También ha tenido presencia como candidato y ganador al mismo reconocimiento en los premios BAFTA y Globos de Oro. Sus películas han tenido una gran repercusión en la sociedad, obteniendo alabanzas de la crítica y premios de suma importancia en el panorama cinematográfico. También ha dirigido series, anuncios de televisión, videoclips e, incluso, participado como actor en cortometrajes.

Toda la información relacionada con su persona profesional y sus películas ha sido contrastada con la base de datos de cine más grande que existe en la actualidad, IMDb (Internet Movie Database). Tiene un amplio recorrido, es conocida en todo el mundo y, actualmente, pertenece a la multinacional Amazon.

Cuenta en su haber con diez películas como director, la mayoría de las cuales ha obtenido una gran repercusión en, prácticamente, todo el mundo y ha llegado a un gran número de espectadores. Esta investigación tratará de analizar la presencia de la mujer en las películas El club de la lucha y La red social.

Es fundamental comenzar con el estudio de diversas teorías acerca del papel que juega el receptor a la hora de interpretar un texto literario, televisivo o cinematográfico. Son muchos los teóricos que han analizado la Teoría de la Recepción Literaria, y otros tantos los que la relacionan directamente con textos cinematográficos. Víctor Hernández-Santaolalla en su artículo De la Escuela de Constanza a la Teoría de la Recepción Cinematográfica. Un viaje de ida y vuelta realiza un análisis de todo este proceso de estudio incluyendo su origen y los autores más destacables.

"Si bien podemos encontrar orígenes que anticipan una preocupación por el receptor, será Hans Robert Jauss quien hable por primera vez de la Teoría de la Recepción (o Estética de la Recepción) en la conferencia inaugural La historia literaria como una provocación a la ciencia literaria (...) Jauss habló de la necesidad de rescribir la historia literaria teniendo en cuenta no tanto la autoría o la obra en sí misma, como se venía haciendo hasta el momento, sino ante todo 
la recepción, pues es esta la que, al fin y al cabo, da sentido a los textos" (HernándezSantaolalla, 2010: 198).

Por tanto, esta teoría proporciona al receptor el poder de completar la historia de un autor con su interpretación. Aquí, es fundamental diferenciar entre los conceptos de texto y obra. Wolfang Iser establece una clara diferenciación que reside en el receptor, por tanto; un texto se convierte en obra cuando es interpretada por el receptor (1989: 149). Se puede definir obra como la conjunción entre el texto del autor y la interpretación del receptor.

Esta interpretación se rige fundamentalmente por el contexto y la propia conciencia del espectador, que le guían para la obtención de un resultado final. Este proceso es analizado por diversos autores con los conceptos de Horizonte de Expectativas y Vacíos o Lugares de Indeterminación.

Los Vacíos o Lugares de Indeterminación son aquellos espacios en blanco presentes en el texto. Los autores tienen medios finitos, por lo que resulta imposible contar todo. Roman Ingarden lo define como lugares de indeterminación en La obra de arte literaria en 1931 y Wolfang Iser establece el concepto de vacíos en La estructura apelativa de los textos en 1989.

El horizonte de expectativas se define como aquellas suposiciones que realiza el espectador para rellenar esos vacíos o puntos de indeterminación. Roman Ingarden define este proceso como concretización.

Ambos autores analizan conceptos que se consideran como sinónimos en la actualidad. No obstante, tienen alguna diferencia.

\footnotetext{
"Las nociones de indeterminación y concretización conducen, en Ingarden, como se ha dicho ya, a consideraciones de tipo metafísicas. En el caso de Iser, en las consideraciones sobre los espacios vacíos prevalece la idea de articulación entre texto y lector, desarrollada con base en el enfoque de la pragmática. Ambos se ubican en una perspectiva estética; no obstante, lo hacen de manera diferente" (Tornero, 2005: 171).
}

Estos conceptos son traspasados al cine como la Teoría de Recepción Cinematográfica. Janet Staiger afirma que, al igual que ocurre con textos literarios, la interpretación del receptor mediante su contexto y sus conocimientos es fundamental para el estudio y la concepción de una obra cinematográfica. Una película está incompleta hasta la interpretación de cada uno de los receptores, convirtiéndose así en una obra 
cinematográfica. No obstante, aunque esta interpretación está a cargo de los espectadores, los autores de cada película dan una serie de pistas y pautas para ello.

Allen y Gomery realizan una enumeración de antecedentes o mecanismos generativos que interactúan para determinar el modo en el que un público interpreta una película. Es decir, una serie de factores que construyen el horizonte de expectativas del receptor:

- Estilo cinematográfico: "uso sistemático de técnicas cinematográficas específicas que caracterizan una película determinada o un grupo de películas" (1995: 114).

- Antecedentes intertextuales: influencias de la estética del cine predominante. "Para el público, representa una parte importante de su horizonte de expectativas, estableciendo el aspecto visual y sonoro que «supuestamente» debe tener una película" (1995: 118).

- Sistemas de producción: "estructura global de organización en la producción de una película" (1995: 120). Engloba las tecnologías utilizadas, las empresas responsables, razones para hacerla, etcétera.

- Autoría: el cine como arte. Lenguaje propio de cada autor creando una estructura en la mente del espectador respecto a lo que espera de cada uno de ellos (1995: 122-124).

- Discurso estético del cine: lo conforma los diversos mensajes que provienen de la publicidad y la crítica (1995: 125-126).

Tal y como afirma Hernandez-Santaolalla, esta clasificación no está completa, "ya que no tiene en cuenta las influencias del contexto sociocultural e histórico en el que se encuentra el espectador real [...] también se podría añadir un elemento más: los actores y actrices que intervienen" (2010: 215).

Todo esto ayuda a comprender los sistemas de interpretación de los espectadores respecto al cine y a los mensajes que transmiten los autores. Los vacíos son llenados de manera acorde a los factores mencionados anteriormente. En la actualidad, estos factores de Allen y Gomery sumando los añadidos por Hernandez-Santaolalla, están muy presente en la decisión de los espectadores para elegir qué película consumir y cómo interpretarla.

Existen pautas que se utilizan en numerosas ocasiones por los autores de cine que llegan a calar en el subconsciente de los receptores, creando o potenciando estereotipos 
claramente diferenciados. En el caso de la diferencia entre géneros, resulta interesante y obligatorio estudiar la posible desigualdad contra el género femenino.

En los últimos años, cada vez es más frecuente la lucha contra estos estereotipos y la desigualdad de género por parte de diversos autores de cine. Hemos podido ver las primeras teorías feministas que reflexionan sobre el cine hecho por mujeres y el papel de la mujer en el cine clásico.

"Las primeras teorías feministas sobre cine se desarrollaron en Estados Unidos y en Gran Bretaña reflexionando y analizando -principalmente sobre el cine hecho por mujeres. Como antecedente podemos mencionar el primer Festival Internacional de Cine de Mujeres de Nueva York (1972) y el Festival de Mujeres y Cine de Toronto (1973), los cuales coinciden con la publicación de tres libros de crítica feminista: From reverence to rape, de Molly Haskell (1975); Popcorn Venus (1973), de Marjorie Rosen; Women and their sexuality in the New Film (1974), de Joan Mellen. En estos años también se lanzó la revista estadounidense Women and Film. Estos textos 'pioneros' buscaron examinar el lugar de la mujer en el cine clásico presuponiendo la existencia de un vínculo entre mundo real y representación cinematográfica. En la misma época en Gran Bretaña, dos sucesos propiciaron un primer acercamiento a la teoría feminista del cine: la proyección de 'cine de mujeres' en el Festival de Cine de Edimburgo (1972) y la publicación de Notes on Women's Cinema (1973), editado por Claire Johnston. La corriente británica se apoyó en las disciplinas, teorías y métodos que -por entonces- estaban siendo utilizados por la teoría fílmica en general” (Iadevito, 2014: 219).

A pesar de estos estudios y publicaciones, sigue siendo mayoritario el cine basado en estereotipos clásicos de género — quedando en entredicho la igualdad—. "La ideología machista no se manifiesta en la «pobreza» de la presencia femenina, sino en situar a la mujer en un universo sin tiempo, poblado de entidades absolutas y abstractas" (Casetti, 1994: 253). No se trata de una cuestión meramente cuantitativa, son muchos los aspectos que se deben estudiar para evaluar el grado de machismo existente en el cine. Actualmente, existe una clara diferenciación entre el cine feminista y el cine clásico predominante, considerado por muchos como cine machista.

Por todo esto, han surgido diferentes estudios y métodos para determinar la existencia o no de una brecha de género discriminante hacia la mujer. Ninguno de ellos es definitivo, incluso su metodología se aleja de ser considerada como científica. No obstante, la suma de sus resultados será de gran ayuda para el desarrollo de la investigación.

El test de Bechdel es un método para determinar si una representación artística cumple con una serie de estándares mínimos para evitar la brecha de género. Se originó en 1985 
en el comic Unas lesbianas de cuidado de la autora Alison Bechdel. La creación del test se le atribuye a una amiga de la autora, Liz Wallace.

La tira cómica cuenta la historia de dos mujeres que se disponen a entrar en el cine cuando una de ellas admite que solo accede a ver aquellas películas que cumplen con tres requisitos; que haya al menos dos personajes femeninos, que compartan alguna escena hablando entre sí y que alguna de esas conversaciones no trate sobre hombres. Estos requisitos se convirtieron posteriormente en el Test de Bechdel.

La autora de esta tira cómica, se inspiró en el ensayo Una habitación propia de la autora Virginia Woolf. Donde critica que la aparición de los personajes femeninos en las obras de ficción se debe exclusivamente a un vínculo con algún personaje masculino existente.

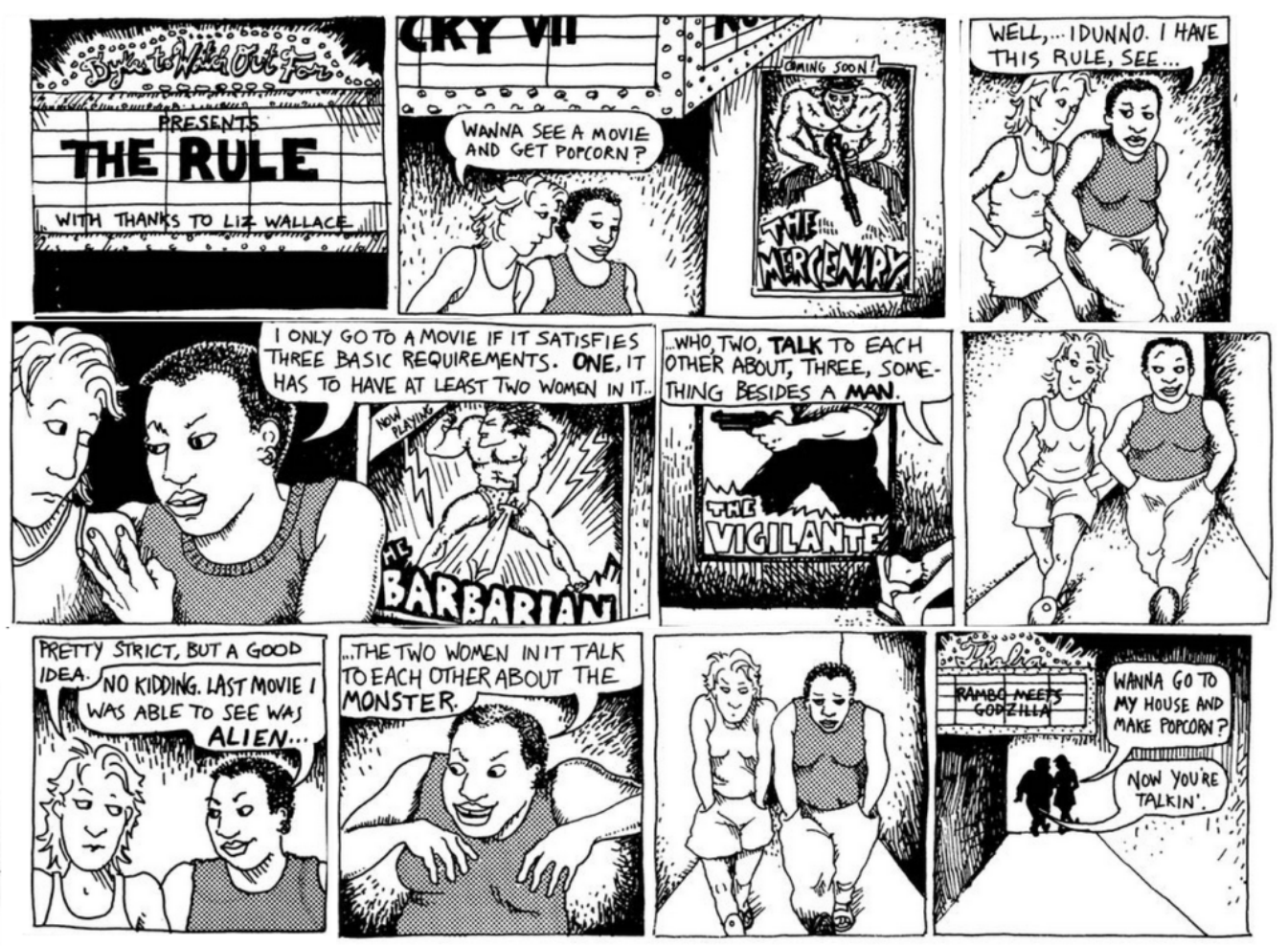

Imagen 01: Unas lesbianas de cuidado (pág 22, Alison Bechdel)

EI test de Mako Mori surgió en Tumblr, en el blog de un usuario llamado Chaila. Su nombre se debe al personaje femenino Mako Mori de la película Pacific Rim. Se trata de un personaje que lucha por sus sueños, que es respetado en todo momento, que no llega a ser sexualizado y que huye de los clásicos estereotipos femeninos. Durante la película, demuestra su fortaleza para cumplir sus sueños. El test, con una clara 
influencia del test de Bechdel, plantea tres requisitos; la película debe contar con al menos un personaje femenino, que debe tener su propio arco argumental y que dicho arco no debe existir exclusivamente para hacer avanzar la trama de un hombre. A pesar de su falta de valor científico, resulta especialmente interesante plantearse estas cuestiones en las películas analizadas.

También resulta interesante el Test de la mujer en el frigorífico creado por Gail Simone, guionista de comic. Sirve para analizar el trato vejatorio y la irrelevancia que sufren los personajes femeninos en las obras artísticas. Está inspirado en una viñeta de 1994 de un comic de Green Lantern. Trata de realizar un recuento de la cantidad de veces en la que el personaje femenino es una víctima, sin embargo, es el protagonista masculino el centro de atención de la escena; que sufre por ella, la contempla o la escucha.

El Test de la lámpara sexy trata de demostrar la presencia irrelevante de la mujer en el cine. Consiste en determinar su un personaje femenino puede ser sustituido por una lámpara, si es así; estamos ante un aspecto machista de la película en cuestión. El término sexy es acogido en clara alusión a la sexualización de la mujer en la gran pantalla.

\section{Objetivos y metodología}

El objetivo principal de esta investigación es defender la hipótesis de que en las películas La red social y El club de la lucha del director David Fincher existe una brecha de género que resulta discriminatoria para la mujer. Por otro lado, se pretende determinar el grado de machismo que representa cada una de las películas del director, sacando conclusiones científicamente válidas.

En último lugar, se pretende establecer a través de la metodología creada para esta investigación, un método fiable para determinar el grado de machismo que puede existir en cualquier película.

La metodología utilizada en esta investigación es un análisis narrativo del contenido de las diferentes películas del director. Para ello, el estudio se divide en dos partes bien diferenciadas. 
En primer lugar, a modo de introducción, un análisis general del cine de David

Fincher. Se tratarán aspectos relevantes como el sexo de los personajes protagonistas, el argumento, la comparación entre los diferentes textos de la misma historia y los resultados obtenidos por el test de Bechdel. Para esto último, se ha utilizado el sitio web www.bechdeltest.com donde son los usuarios de todo el mundo los que se encargan de realizarlo y argumentar los resultados. Esto aportará una visión general y objetiva de los trabajos realizados por Fincher como director.

La segunda parte consiste en el análisis específico de las diferentes películas del director. En cada una de ellas, se analizará objetivamente los personajes, las escenas donde aparecen mujeres y la realización de diversos test que han proporcionado otros autores.

Para este análisis específico y objetivo se han utilizado los conceptos que aportan Francesco Casetti y Federico di Chio en su libro Cómo analizar un film.

\begin{tabular}{|c|c|c|c|c|c|}
\hline \multirow{2}{*}{\multicolumn{3}{|c|}{$\begin{array}{l}\text { Personaje: } \\
\text { Atractivo: }\end{array}$}} & \multicolumn{3}{|l|}{ Profesión: } \\
\hline & & & \multirow{2}{*}{ Físico } & \multicolumn{2}{|c|}{ Mental } \\
\hline \multicolumn{2}{|c|}{ Persona } & Rol & & \multicolumn{2}{|c|}{ Actante } \\
\hline Plano & Redondo & Activo & Pasivo & Estado & Acción \\
\hline Estable & Inestable & Modificador & Conservador & Pragmático & Cognitivo \\
\hline Estático & Dinámico & & & Orientador & No orien. \\
\hline
\end{tabular}

Tabla 01: Ficha de personajes. Fuente primaria.

Los personajes han sido analizados con la ayuda de una ficha elaborada específicamente para esta investigación. Cada uno de los personajes que aparecen de manera frecuente será analizado bajo los conceptos que aparecen a continuación. Para que la presencia de un personaje sea calificada como frecuente, debe aparecer en tres escenas como mínimo.

La profesión proporcionará datos de relevancia para el análisis de estereotipos de género y la importancia y reputación que adquieren cada uno de estos personajes. El atractivo ofrece resultados válidos e interesantes para comprobar el grado de sexualización. Para determinar si un personaje es atractivo o no, se recurre al argumento y al tratamiento que tienen otros personajes respecto al analizado. Es decir, si el personaje es considerado como atractivo dentro del argumento. Puede ser un atractivo físico (por su cuerpo) o mental (por su forma de pensar, su profesión, sus éxitos, etcétera). 
El análisis continuará considerando al personaje como persona, rol o actante. En primer lugar, "analizar al personaje en cuanto a persona significa asumirlo como un individuo dotado de un perfil intelectual, emotivo y actitudinal [...] Lo que importa es convertir al personaje en algo tendencialmente real" (Casetti y di Chio, 2007: 159). Para ello, se recurre a una serie de conceptos:

- Plano o Redondo: En función de si el personaje se presenta como simple, aquel fácil de entender y con pocos detalles diferenciales; o compuesto, todo lo contrario.

- Estable o Inestable: en función de los estados emocionales del personaje.

- Estático o Dinámico: en función de la posible evolución que sigue el personaje durante la historia.

Por otro lado, el personaje como rol; “centrándose en el «tipo» que encarna [...] se pondrán de relieve los géneros de gestos que asume [...] y las clases de acciones que lleva a cabo" (Casetti y di Chio, 2007: 160). Por ello, se tienen en cuenta los siguientes conceptos:

- Activo o Pasivo: si las acciones que realiza el personaje son realizadas por iniciativa propia o ajena, respectivamente.

- Modificador o Conservador: en función de si el personaje pretende realizar actos para cambiar el presente (modificador) o pretende conservar el estado actual (conservador).

Por último, el personaje como actante; "otro modo de analizar el personaje consiste en leer tanto su entidad como su actuación desde un punto de vista abstracto [...] se sacan a la luz los nexos estructurales y lógicos que lo relacionan con otras unidades" (Casetti y di Chio, 2007: 164). Es decir, este punto trata de definirlos en función de las relaciones existentes entre los propios personajes. Se realiza una selección de los siguientes conceptos:

- De Estado o De Acción: si tiene algún nexo de unión con otro personaje (de estado) o no. Ya sea amistad, romance, parental, etcétera. Para que el nexo sea considerado como relevante y, por tanto, sea indicado así en su ficha; debe basar su presencia en la película en este nexo.

- Pragmático o Cognitivo: si realiza acciones directas o, por el contrario, exclusivamente mentales. 
- Orientador o No Orientador: si el personaje guía y orienta a algún otro o, por el contrario, no tiene ninguna relevancia para el resto de personajes.

Por otro lado, se realiza un análisis de aquellas escenas dónde aparecen personajes femeninos. Se analizará la acción en sí para determinar, bajo los conceptos teóricos adquiridos, la función u objetivo que tiene la mujer en cada escena y si su comportamiento es dependiente o independiente (en función del motivo por el cual aparece y ejecuta su función, será dependiente si su estancia en la escena está condicionada a la de un personaje masculino) y transitivo o intransitivo (en función de la relevancia de la acción de la mujer, será transitivo cuando dicha acción es importante para el argumento de la película). También es fundamental destacar, en este apartado, aquellas escenas relevantes para la investigación donde no aparece ningún personaje femenino.

Por último, para complementar toda la información obtenida en apartados anteriores, se realizará un análisis según diversas teorías feministas; el test de Bechdel, el test de Mako Mori y el test de la mujer en el frigorífico. Todos ellos han sido explicados de manera detallada en la introducción.

La mayoría de resultados serán datos cualitativos. No obstante, se cuantificarán en la medida de lo posible para la obtención de datos numéricos y dotar de mayor relevancia a la investigación. Por tanto, se trata de una investigación Mixta.

\section{Análisis y resultados}

\subsection{Análisis general}

El análisis general del cine dirigido por David Fincher ofrece resultados muy relevantes para la investigación. El argumento, los estereotipos utilizados y la diferencia de enfoque que realiza el director frente a las novelas o la película original ofrece resultados muy destacables respecto a la representación de la mujer en sus películas.

Empezando con un análisis del género de los personajes protagonistas, se observa una clara desigualdad a favor del género masculino. Exclusivamente en tres de sus diez películas como director aparece al menos un personaje femenino como protagonista $y$, por tanto, con cierta relevancia para la historia. Es cierto que es posible encontrar 
mujeres que sean relevante para el argumento sin llegar a ser protagonistas, no obstante, estos datos proporcionan argumentos muy válidos para un análisis general. En el siguiente gráfico se observa los porcentajes obtenidos.

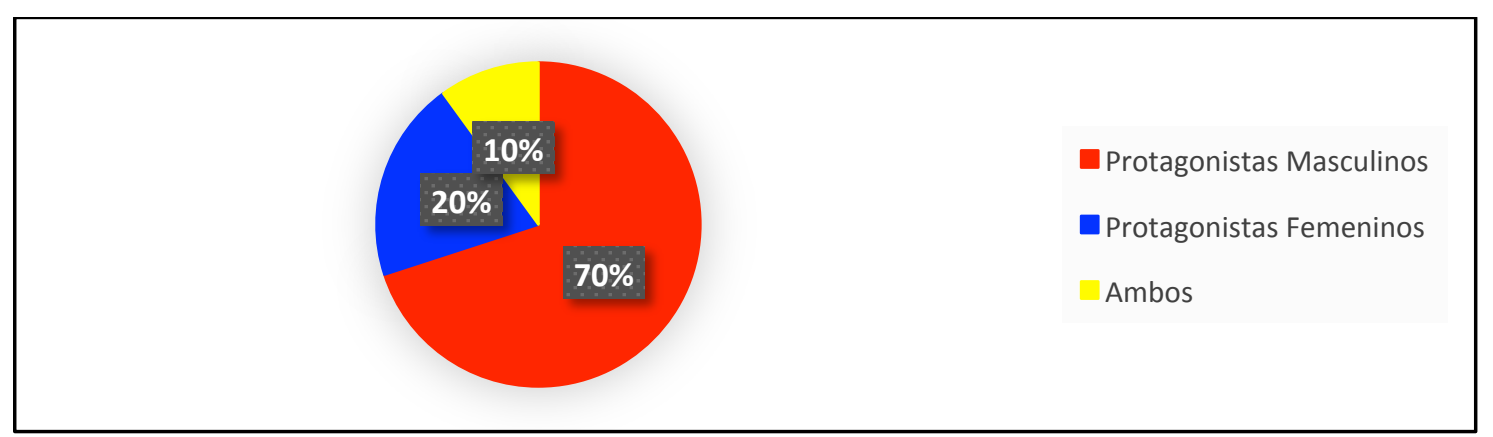

Gráfica 01: Género de los protagonistas del cine de David Fincher. Fuente primaria.

El sitio web www.bechdeltest.com contiene una base de datos muy amplia de películas con los resultados del test de Bechdel. Son los usuarios los que registran las respuestas de las tres preguntas para determinar si el resultado es positivo o negativo para el feminismo y la igualdad de género en el cine. El siguiente gráfico muestra los resultados que aparecen respecto a las películas dirigidas por David Fincher.

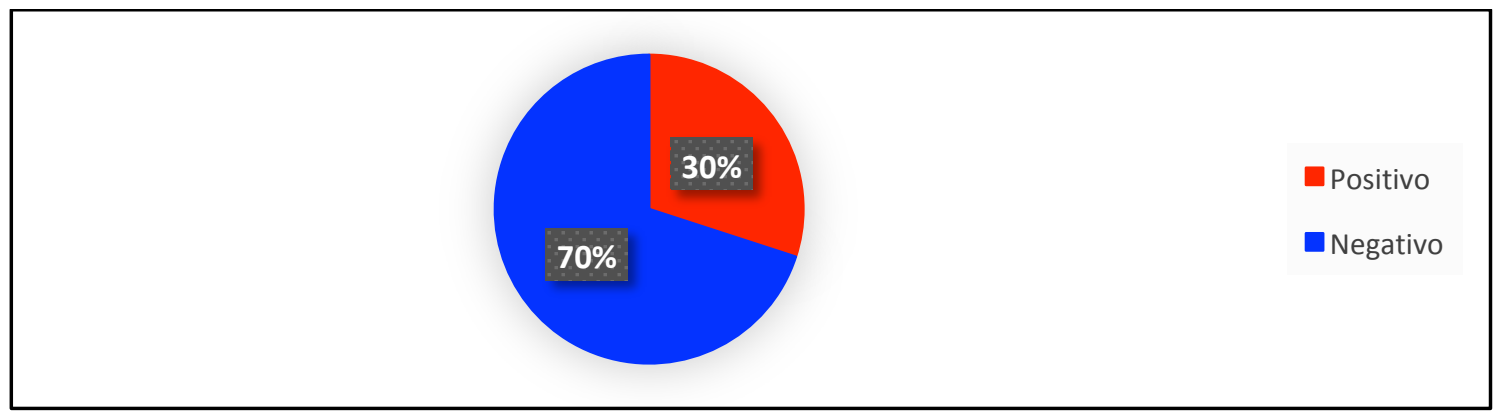

Gráfica 02: Test de Bechdel. Fuente: www.bechdeltest.com.

Los resultados vuelven a ser contundentes, a pesar de ser relativamente fácil el cumplimiento del test, la mayoría de sus películas no llegan a cumplirlo.

A continuación, se trata de manera un poco más específica cada una de las películas partiendo de los resultados obtenidos del sitio web, del argumento y de los personajes. Todo ello aportará una idea general de la representación de la mujer en las películas del director y la relevancia que tuvieron cada una de ellas en la historia del cine. Los premios obtenidos por cada una de ellas, proporcionará una visión general de la importancia alcanzada del director estadounidense y sus películas.

\subsubsection{Alien 3}


Primera película que dirige David Fincher que corresponde a la tercera parte de la famosa saga Alien. A pesar de ser protagonizada por la actriz Sigourney Weaver, el resultado del test de Bechdel es negativo. No aparece ninguna otra mujer en el reparto incumpliendo, por tanto, el primer requisito. Obtuvo diversos premios y nominaciones en algunos de los certámenes más prestigiosos del sector cinematográfico. Especialmente destaca por su nominación a mejores efectos especiales en los Óscar.

\subsubsection{Seven}

Película de suspense y terror protagonizada por dos actores de fama mundial; Brad Pitt y Morgan Freeman. A lo largo de la película aparecen varios personajes femeninos, no obstante, en ningún momento entablan conversación entre ellas. El test de Bechdel vuelve a arrojar un resultado negativo. El personaje femenino con mayor relevancia es la mujer del personaje interpretado por Brad Pitt. Su relevancia en la película es, principalmente, para aportar drama y ser utilizada como amenaza o rehén en contra de los protagonistas. Fue premiado en diversas ocasiones y nominado a mejor montaje en los Óscar.

\subsubsection{The Game}

Al igual que ocurre con Seven, la película fue protagonizada exclusivamente por hombres. Los papeles protagonistas son interpretados por Michael Douglas y Sean Penn. En el reparto, aparece más de una mujer, pero en ningún momento llegan a conversar entre ellas. Por tanto, vuelve a obtener un resultado negativo en el test. No obtuvo ningún premio relevante.

\subsubsection{El club de la lucha}

Película que puede ser considerada como la más valorada del aclamado director. Es protagonizada por Brad Pitt y Edward Norton. Trata de la creación de un club de lucha masculino en la que los integrantes se desahogan luchando entre ellos y realizan actos vandálicos en contra del consumismo y el capitalismo. El resultado del test vuelve a ser negativo, ya que las mujeres que aparecen en la película no llegan a conversar entre ellas en ningún momento. La película es una alabanza a la figura del hombre. Algunos analistas de cine, establecen una relación entre la violencia generada en la película y la homosexualidad ocultada entre líneas. La aparición del cuerpo del hombre semidesnudo es bastante frecuente durante toda la película, llegando a adoptar la postura del David de 
Miguel Ángel uno de los personajes protagonistas. A pesar de no haber obtenido muchos premios, es la película que más repercusión ha tenido del director estadounidense.

\subsubsection{La habitación del pánico}

Primera película del director que arroja un resultado positivo en el test de Bechdel. Protagonizada por dos mujeres; Jodie Foster y Kristen Stewart. Resulta relevante destacar que la película de David Fincher trata sobre la vulnerabilidad de las protagonistas ante una amenaza. Estereotipos muy presentes en el cine de terror en los que la mujer se muestra débil ante la falta de un personaje masculino que le acompañe. Los personajes protagonistas son una madre divorciada y su hija. No obtuvo ningún premio relevante.

\subsubsection{Zodiac}

Es un thriller protagonizado por los actores Jake Gyllenhaal, Mark Ruffalo y Robert Downey Jr. En ningún momento en el transcurso de la película llegan a conversar dos personajes femeninos. Por tanto, el test de Bechdel vuelve a determinar un resultado negativo. No obtuvo premios relevantes.

\subsubsection{El curioso caso de Benjamin Button}

Película protagonizada por Brad Pitt, actor muy frecuente en las películas del director. Se trata de la segunda película que supera el test de Bechdel, según la fuente analizada. Es importante señalar la presencia de estereotipos de mujer como madre y cuidadora, muy presentes en el cine y el contenido audiovisual en general. Recibió grandes premios entre los que se incluyen Globos de Oro, BAFTA y tres Óscar de las trece nominaciones que obtuvo.

\subsubsection{La red social}

Película que trata sobre la creación de la red social Facebook. Está protagonizada por los actores Jesse Eisenberg, Andrew Garfield y Justin Timberlake, y su guion está a cargo del reconocido Aaron Sortkin. Está basada en la novela Multimillonarios por accidente de Ben Mezrich. Aparecen varios personajes femeninos sin apenas relevancia 
en la historia. Según la fuente analizada, el resultado del test de Bechdel es negativo, dado que las mujeres que aparecen no hablan entre ellas. Obtuvo numerosos premios importantes como Globos de Oro, BAFTA y tres Óscar de ocho nominaciones recibidas.

\subsubsection{Los hombres que no amaban a las mujeres}

El director David Fincher, con los actores Daniel Craig y Rooney Mara como protagonistas, realiza un remake de la película sueca de la saga Millenium que a su vez está basada en la novela de Stieg Larsson. A pesar de la paridad de género en el protagonismo, el resultado del test vuelve a ser negativo. Ninguna de las actrices que conforman el reparto mantienen conversación entre ellas. Resulta especialmente relevante que la película de origen sueco sí obtiene un resultado positivo en el test de Bechdel. Obtuvo premios relevantes entre los que se encuentran Globos de Oro, BAFTA y un Óscar al mejor montaje (estando nominado a cinco).

\subsubsection{Gone Girl}

Última película del director estadounidense que pertenece al género dramático. Protagonizada por el actor Ben Affleck. Obtiene un resultado positivo en el test Bechdel. No obstante, no está exento de crítica dado su argumento. La maldad de la mujer está presente durante el transcurso de toda la película, incluyendo su desenlace. Recibió numerosos premios menores y una nominación a los Óscar a mejor actriz.

\subsection{Análisis de La red social}

\subsubsection{Personajes}

\begin{tabular}{|l|l|l|}
\hline \multicolumn{1}{|c|}{ ACTOR } & \multicolumn{1}{|c|}{ PERSONAJE } & \multicolumn{1}{c|}{ DETALLES } \\
\hline Jesse Eisenberg & Mark Zuckerberg & Creador de Facebook \\
\hline Andrew Garfield & Eduardo Saverin & Co-fundador de Facebook \\
\hline Justin Timberlake & Sean Parker & Creador de Napster y accionista de Facebook \\
\hline Rooney Mara & Erica Albright & Ex novia de Mark \\
\hline Joseph Mazzello & Dustin Moskovitz & Co-fundador de Facebook \\
\hline Rashida Jones & Marilyn Delpy & Abogada oyente \\
\hline Armie Hammer & Cameron Winklevoss & Co-fundador de Harvard Connection y remero \\
\hline
\end{tabular}




\begin{tabular}{|l|l|l|}
\hline & & profesional \\
\hline Armie Hammer & Tyler Winklevoss & $\begin{array}{l}\text { Co-fundador de Harvard Connection y remero } \\
\text { profesional }\end{array}$ \\
\hline Max Minghela & Divya Narendra & Co-fundador de Harvard Connection \\
\hline Brenda Song & Christy & Novia de Eduardo \\
\hline
\end{tabular}

Tabla 02: Reparto principal de La red social. Fuente: IMDb.

Los resultados obtenidos a través de las fichas de análisis son muy variados y es complicado sacar conclusiones fiables al respecto. No obstante, hay ciertos datos que resultan realmente interesante para el propósito de la investigación. Lo analizaremos por bloques.

En primer lugar, la profesión es uno de los aspectos más relevantes para analizar dado sus contundentes resultados. La gran mayoría de personajes masculinos tienen una profesión reputada y han alcanzado grandes éxitos en su sector. Los casos de Mark, Eduardo y Dustin como fundadores de Facebook, los hermanos Winklevoss como remeros y fundadores de Harvard Connection junto a Divya Narendra o Sean Parker como fundador de Napster y accionista de Facebook.

En contraposición, los personajes femeninos son meramente estudiantes, becarias o profesiones menos reputadas socialmente. Christy, Erica y Marilyn son estudiantes que no han conseguido nada relevante en el ámbito laboral. Incluso en el caso de Erica, es menospreciada por estudiar en la Universidad de Boston. Marilyn está de oyente en el juicio completando su formación. La única excepción es Gretchen, abogada de Eduardo Saverin.

Posteriormente, en el análisis de las escenas, veremos como cualquier mujer que aparece de figurante cumple con esta desigualdad de profesión.

El atractivo es, probablemente, el punto que ha arrojado resultados más interesantes de esta ficha de análisis. El total de personajes masculinos que se muestran atractivos en la película se deben a su forma de ser, sus éxitos y, en definitiva, a aspectos mentales. El total de personajes femeninos que se muestran atractivas son exclusivamente debido a su físico. Incluso los personajes femeninos secundarios, son admirados por su belleza física. Tenemos los ejemplos de la becaria de Facebook, las diversas chicas que frecuentan fiestas o las modelos de Victoria's Secret. 
En cuanto al primer bloque, los atributos de personajes como personas proporcionan datos dispares que no permiten obtener conclusiones fiables para la investigación. En ambos géneros encontramos diversidad en los conceptos analizados.

Los atributos de personajes como roles también aportan datos muy variados. No obstante, resulta interesante el hecho de que exclusivamente sean hombres los que muestran un rol modificador, con claras intenciones de cambiar el presente por algo mejor para sus intereses. Mark y Sean por un lado y los hermanos Winklevoss y Divya por otro. Todo el argumento de la película gira en torno a esto.

En el último bloque, los atributos de personajes como actantes vuelven a arrojar resultados parecidos al anterior bloque. Son los mismos personajes masculinos los que no tienen ningún nexo de unión destacable con otros. Los únicos que se muestran como personajes de acción y orientadores. Sin embargo, la totalidad de personajes femeninos deben su aparición en la película a un nexo de unión con algún personaje masculino. Ser novia de, amiga de o trabajadora de son algunos de los casos más destacables.

\subsubsection{Escenas}

El análisis de las diferentes escenas donde hacen acto de presencia los diferentes personajes femeninos arrojan resultados realmente interesantes para este estudio. Se han analizado treinta escenas de la película; casi la totalidad de escenas con presencia femenina. Respecto a las escenas relacionadas con los dos juicios que se celebran durante el transcurso de la película, sólo se han analizado aquellas que han resultado más relevantes para la investigación debido a su poca variación entre ellas.

En primer lugar, el análisis del comportamiento de la mujer nos evidencia la gran dependencia que tienen y su irrelevancia en la historia. En el siguiente gráfico se refleja como en la mayoría de escenas, la presencia de la mujer esta supedita a la de un personaje masculino.

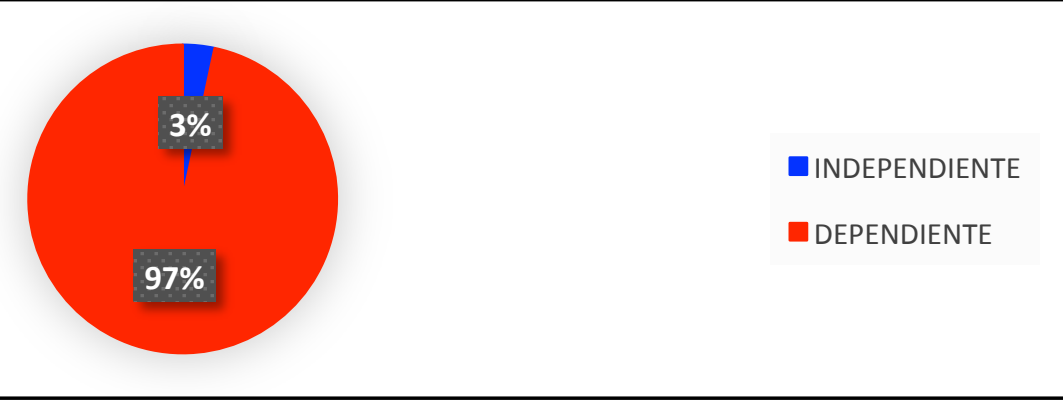


Gráfica 03: Dependencia de los personajes femeninos en La red social. Fuente primaria.

Tal y como se aprecia en el gráfico, sólo en una de las escenas la presencia femenina no depende de algún hombre relevante en la historia. Se trata de la escena en la que un grupo de chicas llega en autobús a una fiesta de un Final Club. El director pretende simplemente mostrarnos este acontecimiento sin la aparición de ningún personaje masculino relevante. La presencia femenina es independiente ya que no tienen relación aparente con los personajes masculinos de la película.

Por el contrario, en el resto de escenas la mujer se muestra totalmente dependiente. Es el caso de la aparición de las diferentes novias, amantes o amigas de los personajes masculinos. La presencia de la exnovia de Mark, la cual solo hace aparición debido a su relación con este. Las apariciones de Christy y Alice, las amigas de Sean Parker o la novia de Dyvia Narendra son claros ejemplos de este tipo de dependencia mostrada. Incluso en el caso del jefe de seguridad de la red de Harvard, resulta relevante la aparición de la mujer como mera figurante; dando el cargo de poder a figuras masculinas.

En cuanto a las escenas de los juicios, tanto los hombres como las mujeres que aparecen como abogados y transcriptores deben su presencia a la demanda entre los personajes masculinos de las cuales trata la historia. Sólo cabe destacar la presencia de Marylin, que en ocasiones muestra sus dotes intelectuales, pero en ningún momento deja de mostrar admiración por Mark Zuckerberg.

En segundo lugar, es indispensable analizar la relevancia de la mujer en la historia. Para ello, se ha analizado si el comportamiento de la mujer en las escenas donde aparecen es transitivo (relevante) o intransitivo (irrelevante). Los resultados generales aparecen en el siguiente gráfico.

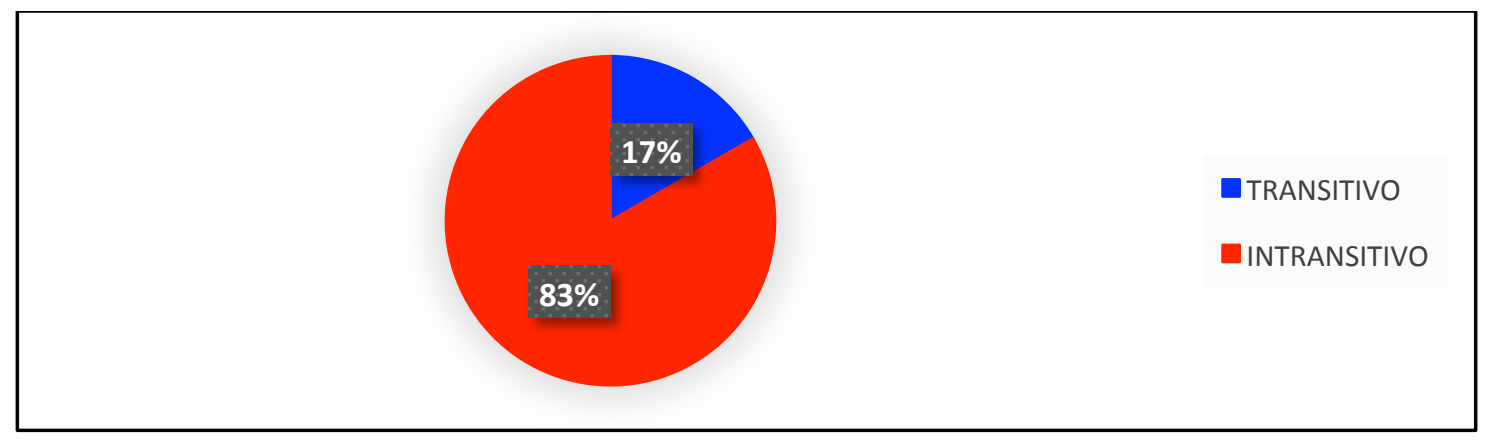

Gráfica 04: Relevancia de los personajes femeninos en La red social. Fuente primaria. 
Vuelve a haber mayoría de importancia del género masculino frente al femenino. Sólo en cinco de las escenas la función de la mujer resulta relevante para la historia. Son los casos de la ruptura entre Mark y Erica con lo que da comienzo a la historia, las muestras de odio hacia el creador de Facebook, que hacen que de algún modo quiera cambiar su imagen, y las reuniones legales que tienen lugar durante la película a raíz de las diferentes denuncias. Cabe destacar que, en estos últimos casos, la presencia de mujeres en los juicios y juntas administrativas es menor que la de los hombres; habiendo, por tanto, un predominio masculino en estas escenas.

En el sentido contrario, nos encontramos con numerosas escenas en las que la actuación del personaje femenino resulta irrelevante para el argumento de la película. Es el caso de la aparición de Alice y Christy que simplemente están allí por la relación con Mark y Eduardo, o las amigas de Sean Parker por la misma razón. Aparecen en multitud de escenas simplemente como objetos de deseo para el hombre, son los casos de las diversas fiestas que aparecen durante la película o, incluso, la aparición de la becaria de Facebook ante la mirada de Mark y Sean.

En diversas escenas aparecen los protagonistas trabajando para la creación y el mantenimiento de su exitosa web. Las apariciones de mujeres en dichas escenas son meramente testimoniales. Se muestran incapaces de realizar trabajos de ese tipo y sus apariciones se deben, de nuevo, a sus relaciones con los personajes masculinos.

Por último, es fundamental el análisis de la función de la mujer en cada acción. El objetivo final que tiene el personaje femenino en cada uno de sus actos. Se ha realizado una agrupación para generalizar las diferentes funciones. Se puede apreciar en la siguiente gráfica.

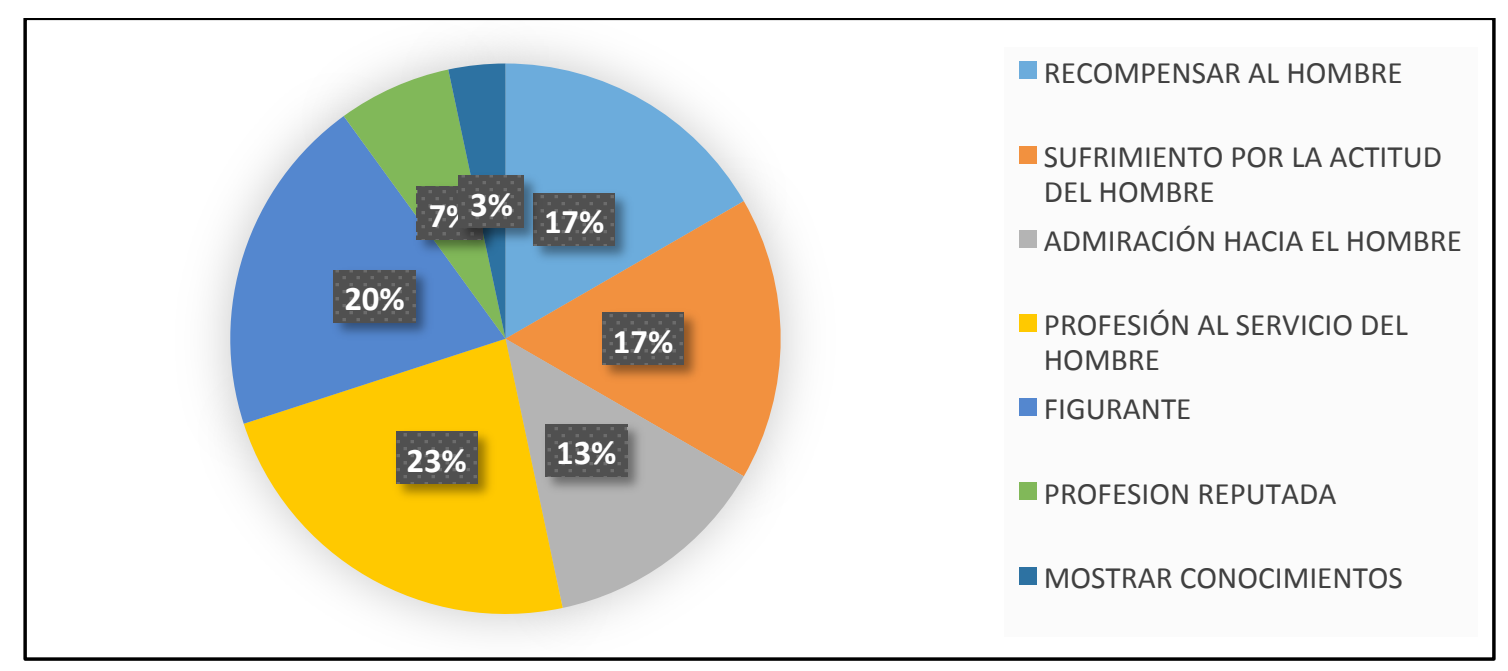


Gráfica 05: Función de los personajes femeninos en La red social. Fuente primaria.

La función más frecuente trata de la aparición de la mujer con una profesión al servicio del hombre. No tiene por qué ser discriminante en sí, pero en la mayoría de ocasiones aparece la mujer asociada a cargos de bajo nivel; como secretarias, camareras o dependientas de cara al público. En contraposición, los personajes masculinos desempeñan altos cargos y profesiones con una mayor reputación; como policías, programadores, inversores, rector de la Universidad o jefe de seguridad de la red de Harvard.

Resultan especialmente relevantes aquellas donde se muestra de manera directa está clara diferencia. La escena en la que un grupo de chicas llegan en autobús a una fiesta, en la puerta se encuentran con dos hombres como porteros o seguratas. Una vez que pasan al local, la camarera que aparece es mujer. Otro ejemplo es la reunión que mantienen Mark y Sean con los dos primeros inversores importantes para Facebook; en recepción le atienden dos secretarias (mujeres) y una vez que pasan a hablar de negocios los inversores son hombres. Otro caso de suma importancia es la escena donde se realiza la selección de programadores para Facebook, todos los candidatos son hombres; la presencia femenina se limita a rellenar los vasos de chupito o animar a dichos candidatos.

También resulta relevante la aparición de una mujer que se dedica a llevar en contador en la regata de remo. Es interesante como la aparición del deporte está relacionada exclusivamente a los hombres, sin embargo, es una mujer la que se encarga de realizar el trabajo menos reputado.

En cuanto a las profesiones relacionadas con la abogacía, hay cierta paridad de género. Encontramos hombres y mujeres ejerciendo la profesión, aunque un menor número de mujeres.

El segundo caso con mayor presencia, es la aparición de la mujer como mera figurante. Es muy frecuente durante la película escenas como la mujer del jefe de seguridad de la red de Harvard, que simplemente aparece a su lado durmiendo y le pregunta sobre qué ha pasado ante una llamada de trabajo. O las diferentes escenas donde trabajan o hablan los responsables de Facebook ante la presencia irrelevante de los personajes femeninos. 
Recompensar al hombre es otra de las funciones predominante. La única escena de sexo está marcada por la presencia pasiva de Eduardo ante la actividad de Christy, que le proporciona placer. En las escenas de diversas fiestas que tienen lugar alrededor de Harvard, ellas aparecen desnudándose o besándose ante la mirada de los chicos.

Otra función negativa de la mujer es mostrar admiración por el hombre. Encontramos varios ejemplos como los elogios que dedica Marylin a Mark en varias ocasiones (en los descansos de los juicios) o la admiración y emoción de Amelia cuando se entera que ha mantenido relaciones sexuales con Sean Parker, creador de Napster.

El sufrimiento por la actitud de un hombre es otra de las funciones que está presente en el texto cinematográfico. Resulta interesante la escena en la que Christy aparece con un actitud posesiva y celosa ante Eduardo. Muestra su rabia y sufrimiento injustificado con el resultado final de una escena cómica. También entran en este campo, las escenas en las que Erica tiene que sufrir la actitud arrogante e insensible de Mark Zuckerberg.

Como funciones positivas para la igualdad de género, tenemos los casos donde la mujer desempeña una profesión reputada y la función de mostrar de conocimientos e intelecto por parte de ellas.

En el primer caso, tenemos la paridad de género ya mencionada en el campo de la abogacía. En segundo lugar, hay una escena donde Marylin muestra sus conocimientos sobre abogacía y juicios ante la torpeza de Mark en este campo.

En definitiva, existe una clara diferencia entre funciones que resultan positivas para la paridad de género y las que resultan todo lo contrario. En el siguiente gráfico se muestra esto.

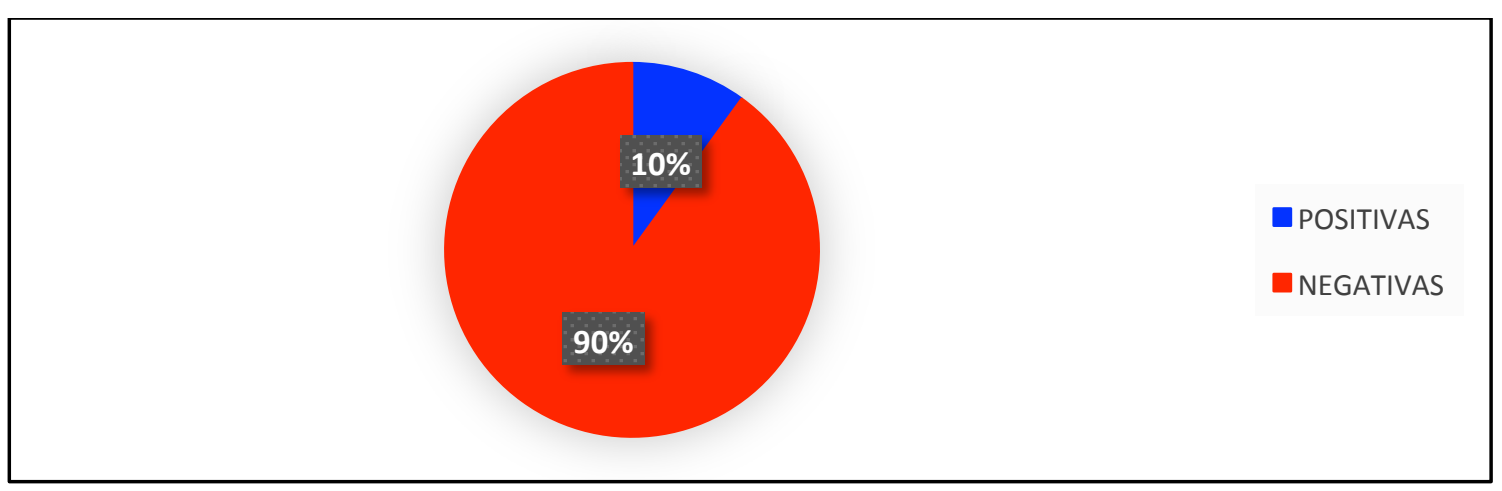

Gráfica 06: Funciones de la mujer en La red social. Fuente primaria.

\subsubsection{Test de Bechdel}


Arroja un resultado negativo. No se cumplen los tres requisitos fundamentales para evitar la brecha de género.

1. ¿Aparecen, al menos, dos mujeres en el reparto de la película? Sí, hay diversas mujeres interpretando papeles que aparecen en la película.

2. ¿Hablan entre sí? La única conversación entre mujeres es a cargo de Erica con una amiga suya cuando descubre el contenido que ha compartido Mark en su blog.

3. ¿La conversación trata sobre otro tema que no sea los hombres? No, la conversación gira en torno a Mark. En la fuente secundaria no llegan a este punto ya que la amiga de Erica no forma parte del reparto principal de la película. No obstante, aun siendo generoso, falla en este tercer punto arrojando un resultado negativo en el test.

\subsubsection{Test de Mako Mori}

Obtiene un resultado negativo. Sólo cumple el primero de los requisitos necesarios para evitar la brecha de género.

1. ¿Cuenta con al menos un personaje femenino? Sí, en la película aparece más de una mujer.

2. ¿Alguna de esas mujeres tiene su propio arco argumental? No, los personajes femeninos de la película apenas tienen relevancia en el argumento.

3. ¿Dicho arco tiene independencia respecto a la trama de los personajes masculinos? Ninguna mujer tiene arco argumental propio.

\subsubsection{Test de la mujer en el frigorífico}

Este test no proporciona resultados relevantes para la investigación de esta película. Aparece reflejado el sufrimiento de mujeres, pero en ningún caso hay un hombre que sea el que sufra por ellas y sea, por tanto, el centro de atención en ese momento.

\subsubsection{Conclusiones}

Tras el análisis de la película, se pueden extraer las siguientes conclusiones respecto a la representación de la mujer en La red social.

\section{- Predominio masculino en el reparto}


La mayoría de actores participantes de la película son hombres. Incluyendo personajes protagonistas, personajes secundarios y figurantes. El protagonismo recae en figuras masculinas y son muy pocos los personajes femeninos que pueden llegar a ser analizados dada sus escasas intervenciones. En las escenas donde se reúnen una gran cantidad de personas, el género masculino suele predominar significativamente.

\section{- Las mujeres son irrelevantes en el argumento}

El hilo argumental de la película gira en torno a los personajes protagonistas. Son ellos los que se muestran como líderes y aportan esas ganas y predisposición por hacer algo grande y cambiar el mundo. La presencia de la mujer se limita a complementar el argumento, todas sus intervenciones tratan de complementar el hilo argumental principal. Se desconoce el pasado de las mujeres y no han conseguido ningún éxito laboral reseñable. Por todo esto, en ningún momento llegan a tener peso significativo en la película.

\section{- Sexualización de la mujer}

La mujer es utilizada como imagen atrayente para los hombres, estableciendo como punto más destacable su apariencia física. Son varias las escenas donde la presencia de la mujer se limita a un tema sexual.

\section{- Estereotipos muy presentes en las profesiones}

Los estereotipos de hombres y mujeres en el terreno laboral, se cumplen en la mayoría de los casos. Podemos ver camareras, secretarias, recepcionistas mujeres, etcétera. Sin embargo, cuando hablamos de profesiones reputadas aparece el hombre; inversores, policías, el rector de la universidad, el jefe de seguridad de la red de Harvard, etcétera. En las profesiones más físicas también aparece el género masculino. Como, por ejemplo, miembros de seguridad o deportistas profesionales. La única excepción encontrada es Gretchen, abogada de Eduardo Saverin.

\section{- Horizonte de expectativas machista}

Los espectadores tendemos a rellenar los vacíos o puntos de indeterminación siguiendo el tono machista de la película. La falta de presencia y relevancia de las mujeres en el argumento, construyen el horizonte de expectativas del espectador obviándolas por completo. Por ejemplo, si en una escena de una fiesta, aparecen mujeres desnudándose 
mientras los chicos las observan, tendemos a pensar que acaban manteniendo relaciones sexuales en los que la mujer es utilizada y tratada como objeto.

\section{- Menor presencia de la mujer}

Sólo hay que contabilizar el número de escenas que pueden ser analizadas por la presencia de personajes femeninos para corroborar la menor presencia de ellas en la película. Se intercalan, en varias ocasiones, varios minutos sin que aparezca ninguna mujer.

\section{- Variedad en los personajes en cuanto a roles y evolución}

A pesar de haber un menor número de personajes femeninos, estos ofrecen comportamientos variados; al igual que los personajes masculinos. En ambos casos tenemos personajes activos o pasivos, estables o inestables y estáticos o dinámicos.

\section{- Personajes femeninos dependientes y conservadores}

La totalidad de mujeres que aparecen representadas en la película, debe su existencia a un nexo de unión de algún personaje masculino. Además, se presentan como conservadoras, sin intenciones de realizar grandes logros que cambien su presente y futuro.

\subsection{Análisis de El club de la lucha}

\subsubsection{Personajes}

\begin{tabular}{|l|l|l|}
\hline ACTOR & PERSONAJE & DETALLES \\
\hline Brad Pitt & Tyler Durden & Creador del club \\
\hline Edward Norton & El Narrador & Creador del club \\
\hline Meat Loaf & Bob & Miembro del club \\
\hline Helena Bonham Carter & Marla Singer & Novia / amante / amiga de Tyler y del narrador \\
\hline Zach Grenier & Richard Chesler & Jefe del narrador \\
\hline Rachel Singer & Chloe & Integrante de un grupo de reuniones. \\
\hline
\end{tabular}

Tabla 03: Reparto principal de El club de la lucha. Fuente: IMDb

El análisis de los diferentes personajes que aparecen de manera frecuente en la película arroja resultados interesantes, aunque no muy destacables para la investigación. 
Especialmente debido a la aparición de un único personaje femenino con cierta frecuencia. Se trata de Marla Singer.

Ningún personaje masculino se presenta como atractivo dentro del argumento. No obstante, el culto al cuerpo del hombre es muy frecuente a lo largo de la película. Aunque se asocia más a la violencia y la agresividad que a lo sensual. Marla, sin embargo, muestra su cuerpo de manera sensual; especialmente en las escenas de sexo, donde únicamente se aprecia el cuerpo femenino.

En cuanto a las profesiones de los personajes principales, no se pueden sacar conclusiones destacables. En algunos casos, incluso se desconoce la profesión. No obstante, si se analiza las apariciones de los figurantes de la película se pueden sacar los siguientes resultados. En la mayoría de los casos, las profesiones con más reputación pertenecen a los hombres; algunos ejemplos son el jefe del personaje protagonista, el médico o altos cargos del gobierno. También se siguen los estereotipos clásicos de género, donde los hombres tienen profesiones más físicas y las mujeres profesiones donde se requiere ser atractiva o simpática. Policías, bomberos, guardias de seguridad o guardaespaldas son profesiones ocupadas por figurantes masculinos. Sin embargo; azafatas de vuelo, telefonistas o reportera de televisión son profesiones desempeñadas por mujeres. Aunque en menor medida, también se encuentran algunos casos que rompen con esto; camareros hombres y dependientes de tienda de ambos sexos.

En cuanto al primer bloque, el análisis de los personajes como personas arroja los siguientes resultados. Los tres personajes principales -El Narrador, Tyler Durden y Marla Singer- se presentan como personas complejas, inestables y dinámicas. Quizás la estabilidad de Tyler sea, en cierto modo, relativa por la seguridad que muestra en la mayoría de las acciones que realiza. No obstante, la conexión con El Narrador y su variedad en las profesiones le proporciona cierta inestabilidad.

En el segundo bloque, referidos a los roles de los personajes, se obtienen resultados muy variados. Lo que hace imposible agruparlo de alguna forma. El personaje femenino, Marla Singer, se muestra activa y conservadora.

Para terminar, en el bloque de personajes analizados como actantes; vuelve a no apreciarse diferencias evidentes entre género. No obstante, la dependencia que muestra Marla a sentirse querida por el hombre está muy patente durante, prácticamente, toda la película. Se muestra en sus inicios como una persona totalmente independiente, de 
acción y pragmática; pero acaba siendo esclava del amor que siente por los personajes principales masculinos. Incluso llega a requerir la ayuda del hombre para salvar su vida en varias ocasiones, en el apartado del análisis de escenas se tratará esto último con más profundidad.

\subsubsection{Escenas}

Se han analizado la totalidad de escenas en la que aparecen mujeres con cierta relevancia en el plano o la conversación. Se han omitido aquellas en las que simplemente salen de fondo. El total de escenas analizadas ha sido treinta.

En primer lugar, se ha analizado el comportamiento de la mujer en cada una de las escenas. Los resultados generales cuantificados nos muestran que, en la mayoría de los casos, la mujer aparece en las escenas por dependencia hacia un personaje masculino. Sin embargo, hay una mayoría de escenas en las que la mujer se muestra relevante para el hilo argumental de la película.

En el siguiente gráfico se aprecia la estadística de la dependencia de los personajes femeninos.

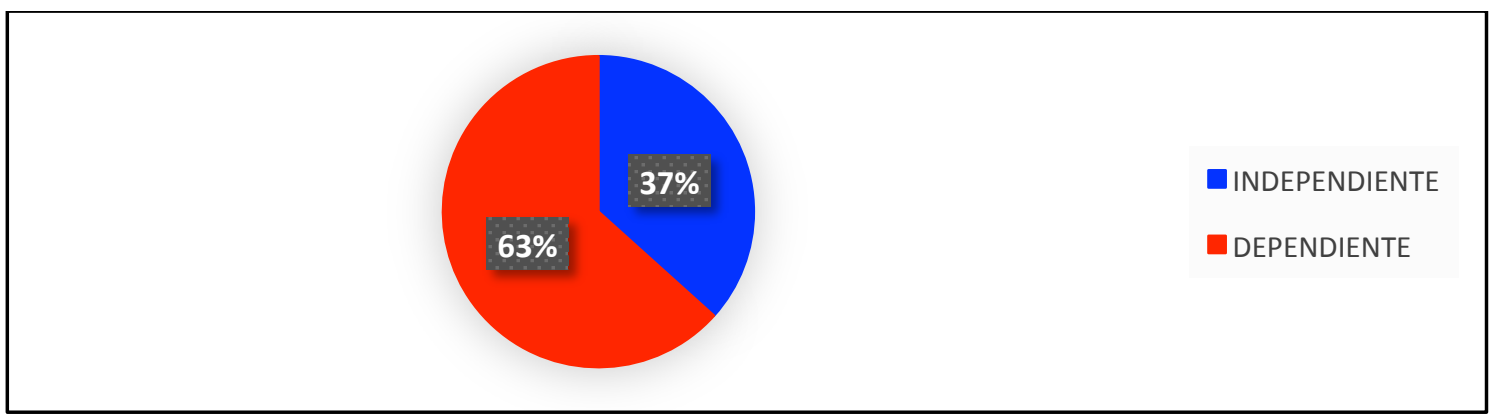

Gráfica 07: Dependencia de los personajes femeninos en El club de la lucha. Fuente: primaria.

Resulta interesante destacar como, al principio de la película, las mujeres aparecen de manera independiente. Una vez establecen relación con los hombres, deben sus apariciones a los personajes masculinos; es decir, al hilo argumental de los personajes protagonistas (Narrador y Tyler Durden). De hecho, desde el minuto cincuenta (aproximadamente) en adelante, en todas las escenas donde aparecen mujeres lo hacen de manera dependiente al hombre.

Marla, la única mujer con relevancia en la historia, aparece y se muestra independiente en los primeros compases de la película, no obstante, con el transcurso de los minutos se establece un nexo de unión entre ella y los protagonistas. La película sigue mostrando la 
historia de Tyler y El Narrador y las apariciones de Marla pasan a ser dependientes de su relación con estos, ya que el argumento gira en torno a ellos.

El hilo argumental de la película gira, en todo momento, en torno a los personajes masculinos. A pesar de la muestra inicial de independencia y fuerza en las mujeres. En la siguiente gráfica se puede apreciar la relevancia de las acciones de la mujer en dicho argumento.

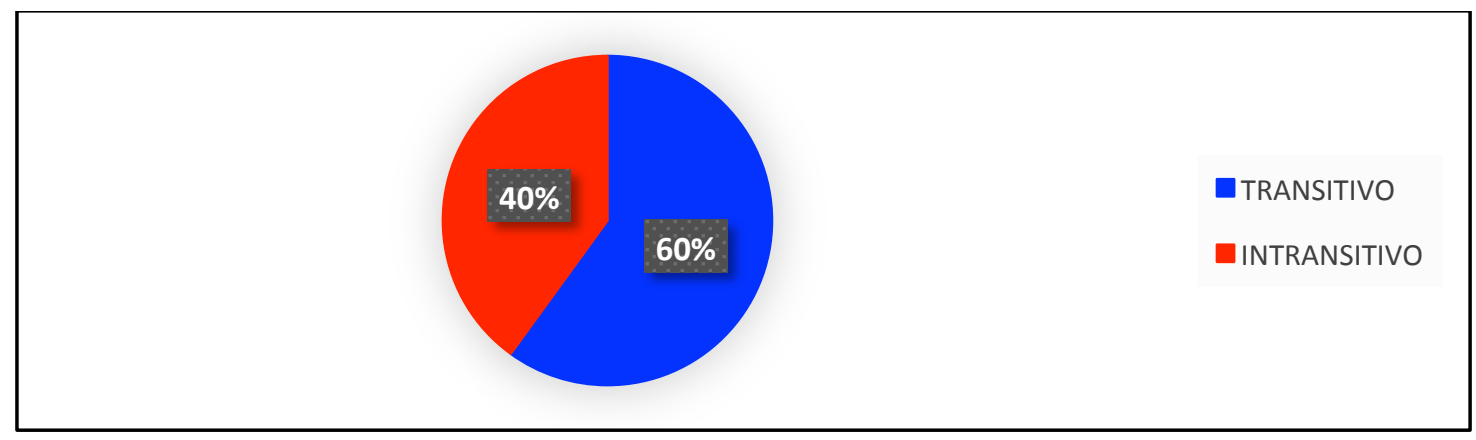

Gráfica 08: Relevancia de la mujer en El club de la lucha. Fuente primaria.

Como se puede apreciar en la gráfica, en la mayoría de las escenas el comportamiento de la mujer tiene cierta relevancia en el hilo argumental. No obstante, se basa primordialmente en los personajes masculinos. Esto hace que la relevancia de dichas escenas tenga la función de complementar la historia de los protagonistas.

Se pueden apreciar ejemplos en las escenas donde se muestra la evolución de la relación entre Marla y El Narrador. El comportamiento de la mujer se muestra como transitivo en las escenas donde se dividen las reuniones de enfermedades, las relaciones sexuales o las escenas finales en las que debaten sobre su relación. En todas ellas, la relevancia de Marla encaja dentro del marco argumental de El Narrador y Tyler Durden.

En la siguiente gráfica se puede apreciar las diferentes funciones que tienen los personajes femeninos en las escenas. Con el fin de conseguir un análisis relevante y fiable para la investigación; se ha agrupado las funciones generalizando, en cierto sentido, las acciones que realizan o sufren los personajes femeninos. 


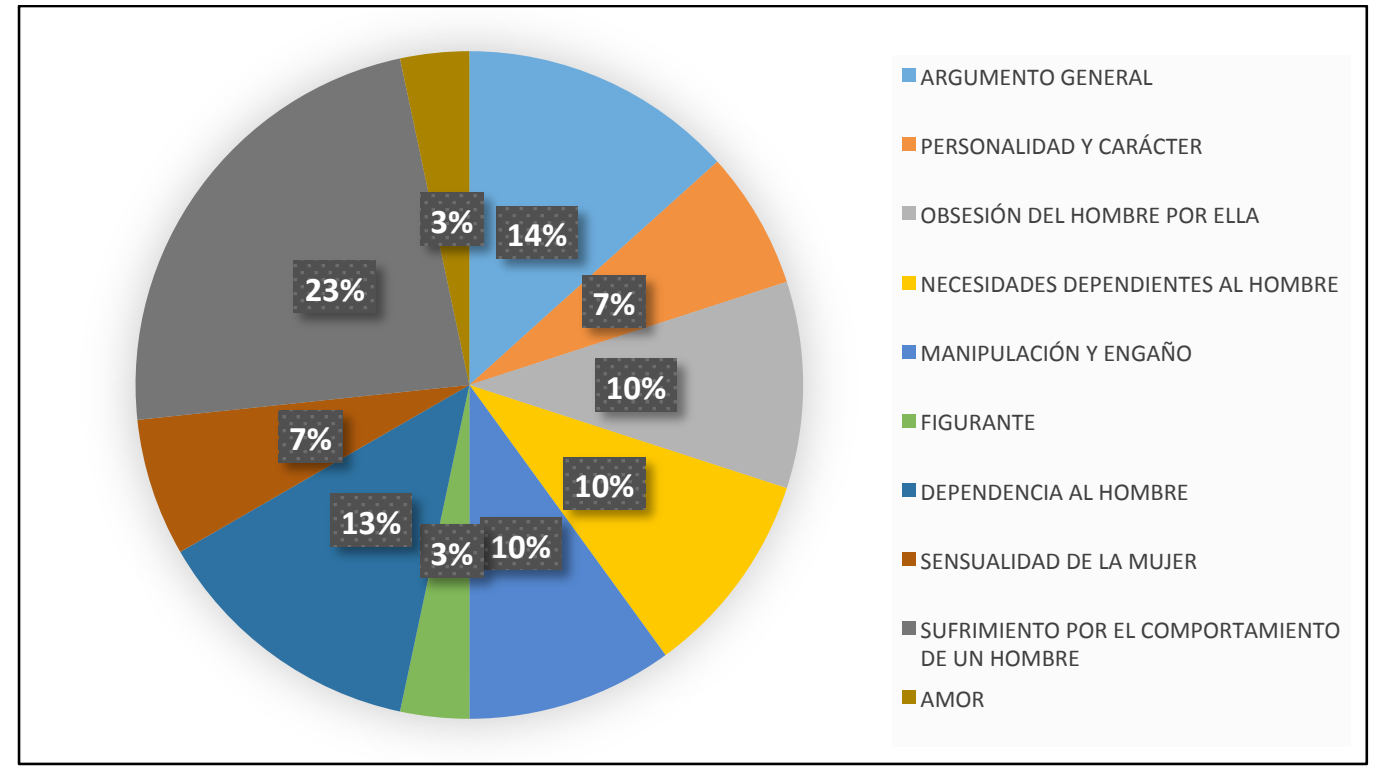

Gráfica 09: Funciones de la mujer en El club de la lucha. Fuente primaria.

La función más frecuente es la muestra de sufrimiento de la mujer por el comportamiento del hombre. En todos los casos en los que se da esta función, se trata de un sufrimiento emocional; fruto de la relación entre Marla y Tyler/Narrador. La inestabilidad, la crisis de identidad y el objetivo que persiguen perjudican enormemente los sentimientos de Marla. Son especialmente relevantes las escenas en las que hablan sobre su relación - con la paradoja de la identidad del protagonista- y las escenas en las que los hombres de Tyler llevan a Marla al edificio de la escena final.

La siguiente función que más se repite son las escenas que tratan de contribuir al hilo argumental de la película. Son los casos de las escenas donde se representan las reuniones entre los que sufren diferentes enfermedades. En ellas, aparecen tanto hombres como mujeres -excepto en las reuniones de hombres que le han extirpado los testículos, lógicamente-. Hay igualdad en el número de representantes de cada sexo. Lo que supone un aspecto positivo para la igualdad de género en la película.

La dependencia de la mujer respecto a los hombres es otra de las funciones que destaca en el análisis narrativo de las escenas. Es muy relevante como en la escena en la que Marla intenta suicidarse pide ayuda a Tyler para que la salve. Igual ocurre cuando piensa que tiene un bulto en los pechos. Muestra dependencia respecto a ellos.

Algunas escenas hacen referencia a la obsesión que adquiere El Narrador con Marla. Las diferentes escenas en las que sueña con ella lanzan un mensaje de obsesión o enamoramiento al espectador. 
También aparecen necesidades dependientes al hombre, esto hace referencia a las escenas donde la mujer muestra unas necesidades que sólo pueden ser cubiertas por el sexo masculino. Una de las escenas de Chloe, en una de las reuniones, invita a los hombres a su casa para mantener relaciones sexuales. Es curioso que es representado como una escena de comedia. Durante la película, no se encuentra ningún caso en el que se inviertan los roles en este sentido.

También es especialmente destacable, la representación de Marla como una persona manipuladora, ladrona y que recurre al engaño siempre que sea necesario. Robando ropa de la lavandería para venderla, robando comida o la facilidad que presenta a la hora de mostrar falsos sentimientos en las reuniones durante las primeras escenas de la película.

En varias ocasiones se aprecia a Marla de manera sensual. En una de las escenas de sexo el único cuerpo que se aprecia es el de la mujer. Incluso otras escenas donde intenta provocar a El Narrador. Durante la película aparece muchísimas veces el cuerpo masculino al descubierto, sin embargo, no se sexualiza de esa forma. Al menos directamente.

Es destacable, en sentido positivo, las muestras que hace Marla de tener un carácter y una personalidad fuerte. Especialmente en los primeros minutos de la película. Llega un momento que se vuelve totalmente dependiente y se muestra sufriendo por la relación.

Por último, el análisis refleja un par de escenas que, a priori, no son especialmente relevantes. Son la consecución del amor en la última escena y la conversación que mantiene El Narrador con una mujer en el avión. Su función únicamente es de figurante.

En la siguiente gráfica se aprecia la cantidad de escenas con funciones positivas y negativas. 


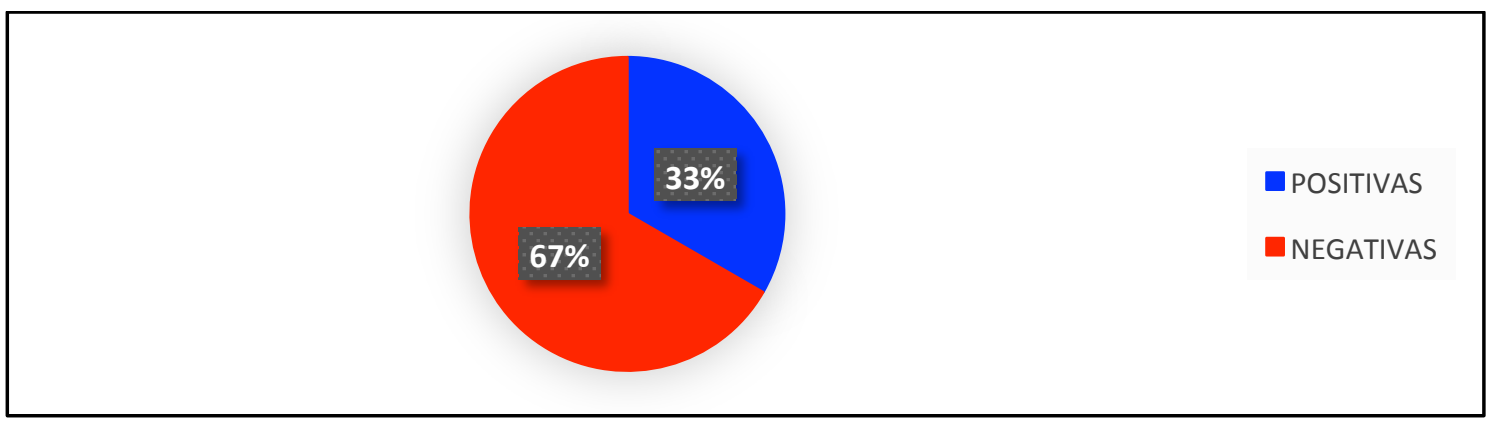

Gráfica 10: Funciones positivas y negativas en El club de la lucha. Fuente primaria.

La mayoría de las escenas tienen funciones negativas para la igualdad de género. Se ha considerado las funciones de amor y obsesión del hombre por ella como funciones positivas, ya que se encuentran en la película casos en personajes de ambos géneros. A estas, se le suma las de argumento general y la muestra de personalidad o carácter.

En contraposición, se ha considerado como negativa las funciones de necesidades dependientes al hombre y sensualidad de la mujer. Debido a que durante el transcurso de la película no se encuentran casos en el género opuesto.

\subsubsection{Test de Bechdel}

Arroja un resultado negativo. No se cumplen los tres requisitos fundamentales para evitar la brecha de género.

1. ¿Aparecen, al menos, dos mujeres en el reparto de la película? Sí, hay diversas mujeres interpretando papeles que aparecen en la película. No obstante, con cierta relevancia en el argumento y los diálogos sólo una.

2. ¿Hablan entre sí? En ningún momento se da una conversación entre mujeres.

3. ¿La conversación trata sobre otro tema que no sea los hombres? En ningún momento se da una conversación entre mujeres.

\subsubsection{Test de Mako Mori}

Obtiene un resultado negativo. Sólo cumple el primero de los requisitos necesarios para evitar la brecha de género.

1. ¿Cuenta con al menos un personaje femenino? Sí, en la película aparecen más de una mujer. 
2. ¿Alguna de esas mujeres tiene su propio arco argumental? No, el personaje de Marla gira en torno al argumento principal del narrador y Tyler Durden.

3. ¿Dicho arco tiene independencia respecto a la trama de los personajes masculinos? Ninguna mujer tiene arco argumental propio.

\subsubsection{Test de la mujer en el frigorífico}

Aunque este test no sea realmente relevante para este tipo de contenido audiovisual, se pueden obtener algunas conclusiones. En las escenas de sufrimiento de Marla, el personaje femenino queda en segundo plano ante el personaje masculino con su crisis de identidad y su doble personalidad. Por tanto, se podría relacionar este contenido al fenómeno que denuncia el test. En este caso, se trata de un sufrimiento mental, no físico.

\subsubsection{Conclusiones}

Tras el análisis de la película, se pueden extraer las siguientes conclusiones respecto a la representación de la mujer en El club de la lucha.

\section{- Predominio masculino en el reparto}

En una película donde el reparto es muy escaso, únicamente aparece una mujer con relevancia en la historia con un mínimo de diálogos y presencia. Respecto a los figurantes hay un predominio claro masculino. El club que da nombre a la película, únicamente está compuesto de hombres.

\section{- Mujer con cierta relevancia para el argumento del protagonista masculino}

Aunque Marla tenga cierta relevancia en la historia contada, todo va en función del hilo argumental del narrador y Tyler Durden. Los resultados en este sentido pueden llegar a resultar engañosos. No hay que olvidar que es una historia hecha por hombres y dirigida a hombres, principalmente.

\section{- Sexualización de la mujer}

Marla, en ciertas ocasiones, es sexualizada y tratada como un objeto sexual. Varias frases resultan relevantes en este sentido; cuando Tyler afirma que tiene relaciones sexuales por deporte o cuando la propia Marla afirma que mantenía relaciones sexuales 
desde primaria. Lo cual deja en la mente del espectador la idea de que ha sido forzada, manipulada o convencida por el sexo opuesto cuando era pequeña.

El cuerpo del hombre aparece en numerosas ocasiones semidesnudo. No obstante, en ningún momento es utilizado de manera sensual directamente, aunque si es representado así. Es decir, el cuerpo masculino aparece como algo bello, pero no llega a ser utilizado para fines sexuales. La violencia entre ellos en el club, con los cuerpos semidesnudos, puede interpretarse como una forma de representar la homosexualidad de manera oculta. En numerosas ocasiones se asocia una relación directa entre la violencia y el sexo.

\section{- Estereotipos muy presentes en las profesiones}

Tal y como aparece reflejado en los resultados, los estereotipos de hombres fuertes y poderosos hacen aparición en la película de David Fincher. Al igual que los estereotipos de mujer en profesiones que se requiere belleza o simpatía.

\section{- Horizonte de expectativas machista}

En la mente del espectador predomina presuposiciones en los que el género masculino es el protagonista. En todo momento son los hombres y Marla. Todos los miembros del club son hombres, lo que hace que el espectador tiende rellenar los vacíos con personajes masculinos.

\section{- Menor presencia de la mujer}

Sólo aparecen treinta escenas en las que aparecen mujeres con cierta presencia en el plano $\mathrm{o}$ en el diálogo. Para una película de dos horas y quince minutos (aproximadamente) es un dato muy bajo y negativo para la igualdad de género.

\section{- Personaje femenino totalmente dependiente}

Marla evoluciona de manera clara a lo largo de la película. Empieza como una persona independiente, con carácter y personalidad fuerte. A lo largo de la película, esta se vuelve totalmente dependiente a sus sentimientos hacia el protagonista masculino. Sin embargo, la evolución de El Narrador y Tyler hace que cada vez sean más fuertes y no muestren tales debilidades antes sus sentimientos.

\section{Conclusiones generales}


Tras el análisis, resulta destacable la existencia de cierto grado de machismo en las películas analizadas. Hay datos objetivos que lo demuestran como el número de personajes femeninos, las profesiones que ejercen o los nexos de unión que tienen con los personajes masculinos. Por tanto, la hipótesis planteada en la investigación queda demostrada.

La metodología aplicada en la investigación es un método fiable para determinar el grado de machismo que existe en una película. Puede ser aplicado a cualquier película y es lo suficientemente efectiva y adecuada para determinar su objetivo con cierta exactitud. No obstante, siempre habrá un grado de relatividad en todos los resultados de este tipo de investigaciones, ya que, la interpretación narrativa siempre podrá estar influenciada por el contexto del investigador. En todas las películas no debe haber el mismo número de hombres que de mujeres, tampoco siempre se va a contar historias con personajes de ambos géneros; la cuestión principal es saber interpretar de lo más general a lo más específico y viceversa, de manera que proporcione un análisis realmente fiable y objetivo de los diferentes textos cinematográficos.

La película La red social es una película con brecha de género con una clara desigualdad para el género femenino. Las diversas conclusiones obtenidas con la investigación determinan una menor presencia femenina, unos personajes femeninos menos relevantes y comportamientos, que son considerados como negativos, que realizan las mujeres que aparecen en la película. La historia basada en la novela y, a su vez, basada en hechos reales debería haber sido más igualitaria en cuestiones de género. Las historias ocurrieron como tal, no obstante, se puede cambiar géneros de personajes al igual que se adornan todas las historias para el lenguaje cinematográfico o darles mayor protagonismo a personajes femeninos y sus logros. Además, hay muchísimos aspectos que se encuentran en segundo plano a la historia principal que presentan síntomas desigualitarios. Como, por ejemplo, estereotipos discriminatorios o la sexualización de la mujer. Por tanto, es una película hecha por hombres que lanza un mensaje de desigualdad a la sociedad que lo percibe e interpreta.

La película $\boldsymbol{E l}$ club de la lucha también presenta claros indicios de desigualdad de género. En menor gravedad, pero se observan determinados aspectos que van en contra de la igualdad de género. Menor cantidad de mujeres en el reparto y menor presencia femenina a lo largo del largometraje. En este caso, al menos, la mujer es presentada con 
carácter y fuerza durante algunas escenas y se encuentran excepciones a los estereotipos clásicos relacionados con las profesiones. Es muy relevante como la mujer acaba siendo totalmente dependiente de sus sentimientos hacia el hombre, dejando en los espectadores un mensaje de debilidad de la mujer. La película se puede considerar como un culto al cuerpo masculino donde la mujer juega un papel muy secundario en el argumento. Siendo el amor su único cometido.

En ambas películas se observan pautas comunes que se repiten. Sexualización de la mujer y muestras del cuerpo femenino como único atractivo posible en las mujeres, estereotipos discriminatorios en las profesiones que desempeñan los personajes, falta de relevancia argumental de los personajes femeninos, minoría en el reparto de las películas y menor presencia a lo largo de ellas - estableciendo una clara desigualdad entre el tiempo que aparecen mujeres y hombres-.

\section{Referencias bibliográficas}

Allen, R.C. y Gomery, D. (1995). Teoría y práctica de la historia del cine. Barcelona: Ediciones Paidós Ibérica, S.A.

Casetti, F. y di Chio, F. (2007). Cómo analizar un film. Barcelona: Ediciones Paidós Ibérica, S.A.

Cassetti, F. (1994). Teorías del cine. Madrid: Ediciones Cátedra, S.A.

De la Serna, C. (2017). Bechdel la prueba del papel de la mujer en el cine. The objetive. (http://theobjective.com/further/bechdel-la-prueba-del-papel-de-la-mujer-en-el-cine/) (06-01-18).

De Lauretis, T. (1992). Alicia ya no. Feminismo, Semiótica, Cine. Madrid: Ediciones Cátedra, S.A.

Hernández-Santaolalla, V. (2010). De la Escuela de Constanza a la Teoría de la Recepción Cinematográfica. Un viaje de ida y vuelta. Revista FRAME, 6; 196-218.

Iadevito, P. (2014). Teorías de género y cine. Un aporte a los estudios de la representación. Revista Universidad Humanística de Pontificia Universidad Javeriana, $78 ; 211-237$. 
Jung, C.G. (2010). Los arquetipos y lo inconsciente colectivo. Madrid: Editorial Trotta, S.A.

Tornero, A. (2005-2006). Indeterminaciones y espacios vacíos en Roman Ingarden y Wolfgang Iser. Anuario de letras modernas, 13; 159-172.

Trivi, M. (2016). Personajes femeninos a examen: 6 herramientas para evidenciar el sexismo. Eldiario.es. (https://www.caninomag.es/los-personajes-femeninos-examen-6herramientas-evidenciar-sexismo/) (08-01-18). 